\title{
Prospective Students' Math Talk in Solving Secondary School Mathematics Problem
}

\author{
Dini Kinati Fardah \\ Mathematics Education \\ Universitas Negeri Surabaya \\ Surabaya, Indonesia \\ dinifardah@unesa.ac.id
}

\author{
Puspita Anggraini Setyaningrum \\ Mathematics Education \\ Universitas Negeri Surabaya \\ Surabaya, Indonesia \\ puspita17030174071@mhs.unesa.ac.id
}

\author{
Evangelista Lus Windyana Palupi \\ Mathematics Education \\ Universitas Negeri Surabaya \\ Surabaya, Indonesia \\ evangelistapalupi@unesa.ac.id
}

\author{
Anggietyas Damaningrum \\ Mathematics Education \\ Universitas Negeri Surabaya \\ Surabaya, Indonesia \\ anggietyasd19@gmail.com
}

\author{
Ahmad Wachidul Kohar \\ Mathematics Education \\ Universitas Negeri Surabaya \\ Surabaya, Indonesia \\ ahmadkohar@unesa.ac.id
}

\begin{abstract}
To activate the cooperation or collaboration skill of the students, educator often make small groups of students and give some topics to be discussed. However, we often ignore the activities that occur within the group. This article describe the process of problem solving occurred in 3 groups of prospective students for 30 minutes. A secondary school mathematics problem given to the eight groups of prospective students. They asked to design several cardboards to pack small cubes and cuboids without any space left. The math talk during the discussion was recorded. The audio files were transcribed and coded into categories of process of understanding problem, devising a plan, carrying out the plan, and looking back. Besides, the transcription was analyzed and categorized into math talk that support or do not support the problem solving. The groups' paper and pencil works were also analyzed to support the transcription. Of 8 groups, the math talk of 3 interesting groups were analysed more and elaborated. The result show that the most of the time the students spent is for solving the problem and the shortest is for understanding the problem. The step that still missed by the several students is looking back. This study impact is that students should enhance their skill to deliver a good argumentation.
\end{abstract}

Keywords - math talk; prospective students; problem solving; discussion; argumentation

\section{INTRODUCTION}

If today's student want to compete in this global society, they have to get used to do good communication, collaboration, critical thinking and problem solving, and creativity and innovation or better well known as the "Four Cs"[1]. To support the student to achieve the skill of those Four Cs, teachers need to make the student familiar with it.

Communication is one part of the Four Cs main focus as well as it is still become interesting study in mathematics education for some time [2]. Designing a cooperative learning is a common things in higher education as it is still believed as one method that have positive impact on students' achievement [3]. To activate students' skill to cooperate and communicate with others, educator often make a small group and give some topics to be discussed. However, we often ignore the interesting conversation that occur within the group. Students' may claim their idea, suggest their thought, state pros or contras, state their position of agree or disagree, explain their work and many other kinds of different form of communication that lead them to draw a conclusion or solve their problem of task given.

Some research emphasis the significant role of representation of mathematics symbol as way of sharing mathematical idea which documented in students' paper and pencil work[4][5]. However, there are still few studies that elaborate the math talk occurred within the discussion process of solving mathematics problem. This paper fill in the vacancy of this enticing topic.

\section{RESEARCH METHOD}

This is a qualitative research. Eight groups of 4-5 prospective students of mathematics education study program were given a problem as presented in figure 1 .

Izza has one set of wooden blocks contains of 16 small wooden cuboids which have dimension of $1 \mathrm{~cm} x 1 \mathrm{~cm} \times 3 \mathrm{~cm}$ and 12 small wooden cubes which have length side of $2 \mathrm{~cm}$. Izza loose the cardboard of her wooden cubes and cuboids. Help her to create new cardboards by determining the size of the cardboard. Explain how you find the size.

Fig. 1. The problem given

Students are asked to do discussion to solve the problem while recorded. The average time the students do the discussion is around 30 minutes. The audio file were then transcribed and coded into categories of math talk in solving problem according to Polya's phase which are understanding the problem, devising a plan, carrying out the plan, and looking back [6]. The data of this categorization 
were presented descriptively. Three attractive groups of eight groups were chosen to be analyzed in depth. Besides categorized as math talk in each problem solving phase, the transcription of the three groups were also categorized into effective and non-effective discussion. The effective discussion were defined as: 1) discussing the solving problem more than $80 \%$ of the time spent; 2 ) the discussion result the correct solution.

\section{RESULTS AND DISCUSSION}

The results were divided into three main parts, they are 1) The general description of 3 groups chosen 2) The categorization of groups' math talk in problem solving phases; 3)The effective and non-effective discussion. The group chosen were named as group 1, 2 and 3.

\section{A. The general description of 3 groups chosen}

Group 1 is the most active group which many ideas of strategy were explored. In this group the math talk done by the group was the richest. All the students try to give their idea and pros and contras occurred a lot in this group. All phases of problem solving were passed repeatedly, especially for carrying out the plan and looking back phase, and in the end of the discussion they get the correct result.

Group 2 is the group in which the discussion went on was the most ineffective. The discussion went on spent more than 20 minutes to obtain their first solution. However, looking back phase was not passed perfectly while other groups do it repeatedly. In the end, this group give an incorrect solution.

Group 3 is the only group that has a talk beyond the topic when solving the problems as. They tried to guess

what the task for, what the recording process means, and what the lecturers' intentions. This group is the most boisterous as agreement and disagreement occur many times in this group. However, the group succeed in solving the problem

\section{B. The categorization of math talk in problem solving phases.}

In this result, each group audio file transcription was analyzed and categorized into math talk in understanding problem, devising a plan, carrying out the plan, and looking back. The result is presented in Table 1.

From the Table 1, we can see that Group 2's discussion is not as effective as the two groups. The first solution obtain by this group is presented in Fig 2 .

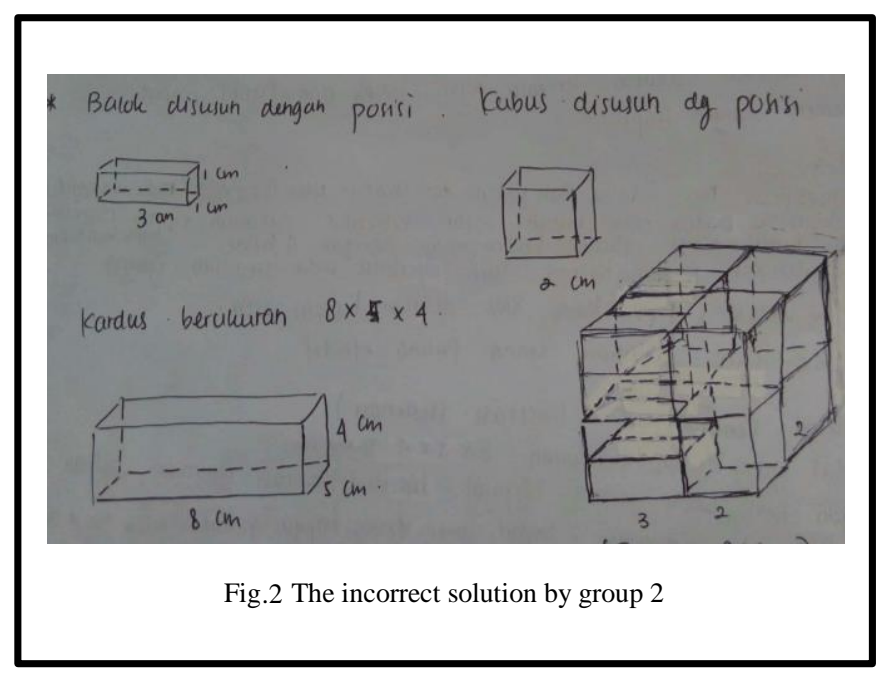

TABLE 1. THE CATEGORIZATION OF GROUPS' MATH TALK IN PROBLEM SOLVING PHASES

\begin{tabular}{|c|c|c|c|c|}
\hline Group & $\begin{array}{c}\text { Math talk in } \\
\text { understanding the } \\
\text { problem }\end{array}$ & $\begin{array}{l}\text { Math talk in Devising a } \\
\text { Plan }\end{array}$ & Math talk in carrying out the Plan & $\begin{array}{l}\text { Math talk in Looking } \\
\text { back the problem }\end{array}$ \\
\hline Group 1 & $\begin{array}{l}\text { By reading the problem, } \\
\text { understanding in each } \\
\text { information given in the } \\
\text { problem }\end{array}$ & $\begin{array}{l}\text { Student } 1 \text { explaining to } \\
\text { compute the volume of all } \\
\text { the cuboids and cubes } \\
\text { Student } 2 \text { adding the strategy } \\
\text { that is trying to do guess and } \\
\text { check whether the size they } \\
\text { guess that correspondence to } \\
\text { the total volume can be used } \\
\text { to pack all the cuboids and } \\
\text { cubes. } \\
\text { Student } 3 \text { suggesting to draw } \\
\text { a } 2 D \text { picture of cuboids and } \\
\text { cube arrangements by using } \\
\text { some colouring pens }\end{array}$ & $\begin{array}{l}\text { All the members actively giving idea of } \\
\text { executing the plan such as reminding } \\
\text { other student to add the layers of cuboid } \\
\text { and cube arrangements, suggesting the } \\
\text { student who doing the drawing how to } \\
\text { draw effectively using 3D picture. }\end{array}$ & $\begin{array}{l}\text { Checking if the volume of } \\
\text { the size of cardboard made } \\
\text { has a volume of } 144 \mathrm{~cm}^{2} \text {. } \\
\text { Checking whether all of } \\
\text { the cube cuboid has been } \\
\text { arranged } \\
\text { Checking whether there is } \\
\text { any space left or not }\end{array}$ \\
\hline Group 2 & $\begin{array}{l}\text { One student reread the } \\
\text { problems, other students } \\
\text { try to guess what the } \\
\text { meaning of the problem } \\
\text { is. }\end{array}$ & $\begin{array}{l}\text { The group agree to use } 3 \mathrm{D} \\
\text { picture to illustrate the cubes } \\
\text { and cuboids arrangement }\end{array}$ & $\begin{array}{l}\text { Each of member stated their own idea. } \\
\text { Every time one student explain their } \\
\text { idea, the other try to listen but without } \\
\text { statement of accepting or agreeing his } \\
\text { idea, the others try to explain their own } \\
\text { idea. }\end{array}$ & $\begin{array}{l}\text { No one realize about the } \\
\text { mistake of the group made. } \\
\text { The picture of this group } \\
\text { solution and the transcript } \\
\text { of their mathematics talk is } \\
\text { presented in figure } 2 \text { and } \\
\text { figure } 3 \text { respectively. }\end{array}$ \\
\hline Group 3 & $\begin{array}{l}\text { One student reread the } \\
\text { problems, other students } \\
\text { try to guess what the } \\
\text { meaning of the problem } \\
\text { is. }\end{array}$ & $\begin{array}{l}\text { All the members of the group } \\
\text { agree to use } 3 \mathrm{D} \text { drawing of } \\
\text { the cube and cuboid } \\
\text { arrangement as the only one } \\
\text { strategy }\end{array}$ & $\begin{array}{l}\text { In carrying out the plan all the members } \\
\text { of the group actively shared their idea of } \\
\text { making the cubes and cuboids } \\
\text { arrangements, but there occur a chaos of } \\
\text { scrambling to give idea. }\end{array}$ & $\begin{array}{l}\text { Along with carrying out } \\
\text { the plan, the students } \\
\text { repeatedly check the } \\
\text { arrangement did not left } \\
\text { any space and all the cubes } \\
\text { and cuboids had been } \\
\text { being arranged. }\end{array}$ \\
\hline
\end{tabular}


From the solution as seen in Fig 2, we can see that actually the group has a good start that is by matching 16 cuboids with 4 cubes. By adding another two-four cubes in the right side of the arrangement they made, actually they will get the correct solution, that is a cardboard with the size of $9 \times 4 \times 4 \mathrm{~cm}$. But, listening to the recorder and analysing more, students mislead that another two-four cubes can be added on the arrangements they had already made.

S1G2 : 1 cube can be matched with 4 cuboids as the surface of cubes is $2 \times 2$ and the cuboid is $1 \times$ 1 .

S2G2 : that's correct.

S1G2 : so, in one layer of 2 lined up cube, we can put 8 cuboids.

S1G3 : yeah, Then, we add the second layer on the first layer with the same arrangement, and the cuboids has all set.

S1G2 : that's what I mean.

S1G1 : and the other cubes can be added on this second layer. So, the width of the cardboard is 5 , the height is 4 , and the length is 8

All members agree with this solution without any rebuttal.
Considering the picture they made, the mistake may happen because of the incorrect scaling picture of $3 \mathrm{~cm}$ cuboid and $2 \mathrm{~cm}$ cube or incorrect representation. Only by seeing the picture, the other members of the group agree that the third layer can be added by four cubes. The conversation is presented in figure 3 .

At first, actually there is one students who has shared the correct idea but he did not explain more about his solution. It is in line with idea of argumentation [7]. A claim should have supported by data and warrant. The student did not share the data and warrant, so that the argument could not be accepted by other students.

\section{The effective and non-effective discussion}

The discussion is said to be effective if more than $80 \%$ of the time students spent for solving the problems and the solution obtain is the correct one. All the three groups spent more than $80 \%$ of their time to solve the problem. However, group 2 failed to obtain the correct solution. The time they spent is not different with other groups and there were no mistake on the strategy they use as well, but they did not pass the looking back phase as often as other groups. The detail of the groups' time spent in doing the phase of problem solving presented in Table 2 .

Fig.3 The mislead math talk by Group 2

TABLE 2. THE GROUPS' TIME SPENT FOR SOLVING THE PROBLEM

\begin{tabular}{|c|c|c|c|}
\hline Group & $\begin{array}{c}\text { Time spent for } \\
\text { understanding the problem }\end{array}$ & $\begin{array}{l}\text { Time spent for } \\
\text { Devising a Plan }\end{array}$ & $\begin{array}{l}\text { Time } \\
\text { spent for } \\
\text { carrying } \\
\text { out the } \\
\text { Plan }\end{array}$ \\
\hline Group 1 & $\begin{array}{l}\text { Need short time (less than } 3 \\
\text { minutes) to understand the } \\
\text { problem }\end{array}$ & $\begin{array}{l}\text { Need about one minute } \\
\text { to combine all the } \\
\text { members' strategy } \\
\text { they will use. }\end{array}$ & $\begin{array}{l}\text { Carrying out the plan couldn't be separated from looking } \\
\text { back phase. In this combined phase, students always do } \\
\text { and check many times so that they solve the problem and } \\
\text { get answer of cardboard size more than one answer. } \\
\text { This phase need } 24 \text { minutes. }\end{array}$ \\
\hline Group 2 & $\begin{array}{l}\text { Need short time (less than } 3 \\
\text { minutes) to understand the } \\
\text { problem }\end{array}$ & $\begin{array}{l}\text { Need about one minute } \\
\text { to combine all the } \\
\text { members' idea of } \\
\text { strategy they will use. }\end{array}$ & $\begin{array}{l}\text { In They do not spent much time to do this } \\
\text { producing phase. } \\
\text { one } \\
\text { cardboard } \\
\text { size, they } \\
\text { spent } \\
\text { around } 17 \\
\text { minutes }\end{array}$ \\
\hline Group 3 & $\begin{array}{l}\text { Need longer time than other } \\
\text { groups (about } 7 \text { minutes) to } \\
\text { understand the problem. } \\
\text { Moreover, in understanding } \\
\text { the problem, they do a talk } \\
\text { that have no relationship with } \\
\text { the problem solving process }\end{array}$ & $\begin{array}{l}\text { Finding the idea of the } \\
\text { strategy only need } \\
\text { about } 2 \text { minutes, but } \\
\text { combining all the } \\
\text { members' idea to write } \\
\text { the strategy in the } \\
\text { worksheet need more } \\
\text { than } 5 \text { minutes. }\end{array}$ & $\begin{array}{l}\text { Carrying out the plan couldn't be separated from looking } \\
\text { back phase. In this combined phase, students always do } \\
\text { and check many times so that they solve the problem and } \\
\text { get answer of cardboard size more than one answer. } \\
\text { This phase need } 23 \text { minutes. }\end{array}$ \\
\hline
\end{tabular}

\section{CONCLUSION}

From the Table 2, we can see that group 2 did the ineffective discussion. They did a long talk to get the solution, but then they did not check it. While the other two groups has more than one correct solution.
It is necessary for educators to look and listen to what activity is occurred within the groups when we decide to organized the students' learning experience using cooperative learning. Audio recorder or video can be used to help it. It is better if the condition of the researcher knowing well the voice or face or name of the students in the class is 
fulfilled. Using audio or video recorder can be used to see how effective the discussion in every group. If there is a group that conduct the discussion ineffectively, we can search for what was happened and what has been being the obstacle during the discussion. As in this study, it is found that a group failed to solve the problem is because of incomplete process of posing an argument. Giving a claim without giving warrant or backing indeed could not be accepted by others. This fact coupled with the lack of awareness to always check the solution or in the problem solving phase called as looking back phase. Other method that can be used to check what is happened within the group is by conducting interview to each members. This may overcome the unfulfilled condition of researcher know well the students in the class.

\section{REFERENCES}

[1] National Education Association, Preparing 21st century students for a global society: An educator's guide to "the four Cs, Washington DC, 2012.

[2] A. K. Nordin and L. B. Boistrup, "Framework for identifying mathematical arguments as supported claims created in day-to-day classroom interactions," J. Mathematical Behav., 2018

[3] R. P. Estebanez, "An Approachment to Cooperative Learning in Higher Education: Comparative Study of Teaching Methods in Engineering," EURASIA, J. Mathematics Sci. Technol. Education, vol.13, pp.1331-1340, 2016.

[4] E. B. Uptegrove, "Shared communication in building mathematical ideas: A longitudinal study,” J. Mathematical Behav., 2015.

[5] R. A. Rahman, Y. M. Yusof, H. Kashefi, and S. Baharun, "Developing mathematical communication skills of engineering students," Procedia - Soc. Behavioral Sciences, vol.46, pp.5541 $5547,2012$.

[6] G. Polya, How to Solve it: A new aspect of mathematical method. Princeton, N.J: Princeton University Press, 1957.

[7] S. Toulmin, The uses of argument, Cambridge, UK: Cambridge University Press, 2003. 